\title{
CANADIAN PRODUCTION IN AND TO AMERICAN MARKETS: BILATERAL TRADING ISSUES
}

\author{
R.W. RIEGERT and R.J. LANE'
}

The main concern of this article is the bilateral trade relationship between the United States and Canada, and specifically trade involving the energy industry. The main areas of the trade relationship are examined. First, the aims of the North American Free Trade Agreement are examined to show how it differs from, expands and improves upon the Free Trade Agreement. Second, four areas of commercial law are examined: The Uniform Commercial Code; U.S. federal legislation designed to control conflicting state laws; products liability dealing with the potential liability of Canadian manufacturers to American consumers; and the United Nations Convention on Contracts for the International Sale of Goods. Third, there is advice to Canadian manufacturers on ways to avoid becoming liable for American tax. Fourth, the harmonization of American and Canadian trade and financial statutes in the areas of countervailing duties, dumping, anti-trust and customs tariffs is discussed. This is followed by advice on the different taxation policies followed by the United States and Canada and the implications for bilateral trade. Provisions for the transfer of possession of products are discussed as are immigration questions raised by the entry of Canadians into the United States to sell their products. Finally, the regulation of interstate commerce in the United States is examined.

\section{TABLE OF CONTENTS}

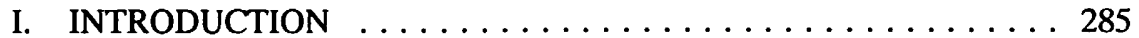

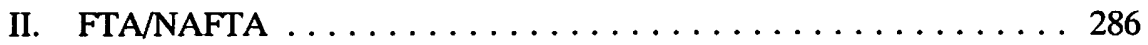

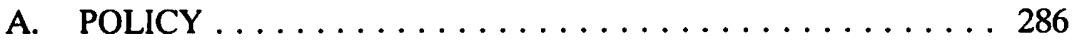

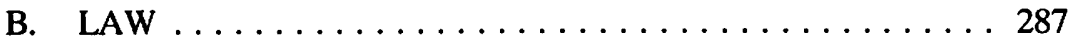

C. BUSINESS IMPLICATIONS $\ldots \ldots \ldots \ldots \ldots \ldots \ldots \ldots 28$

III. COMMERCIAL LAW $\ldots \ldots \ldots \ldots \ldots \ldots \ldots \ldots \ldots \ldots \ldots$

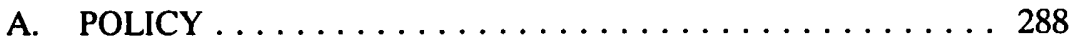

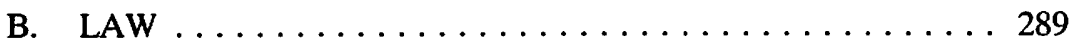

C. BUSINESS IMPLICATIONS $\ldots \ldots \ldots \ldots \ldots \ldots \ldots \ldots$

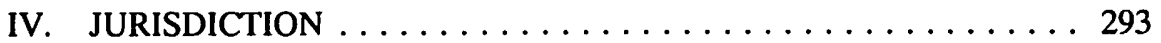

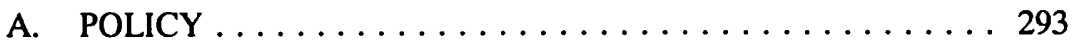

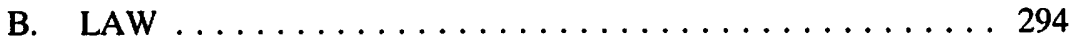

C. BUSINESS IMPLICATIONS $\ldots \ldots \ldots \ldots \ldots \ldots \ldots \ldots$

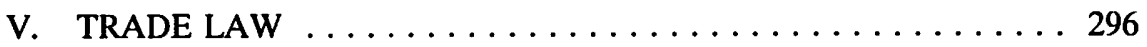

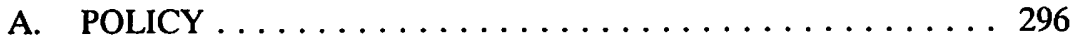

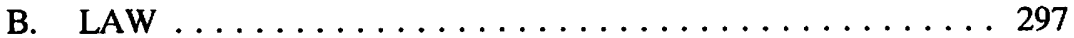

C. BUSINESS IMPLICATIONS $\ldots \ldots \ldots \ldots \ldots \ldots \ldots \ldots$

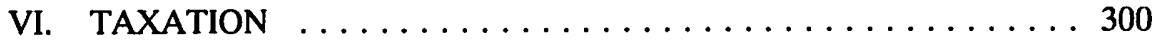

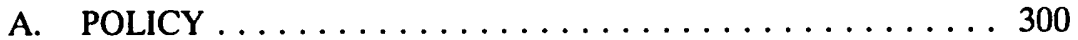

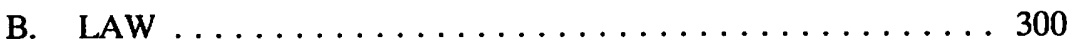

C. BUSINESS IMPLICATIONS $\ldots \ldots \ldots \ldots \ldots \ldots \ldots \ldots 303$

VII. TRANSPORTATION $\ldots \ldots \ldots \ldots \ldots \ldots \ldots \ldots \ldots \ldots \ldots$

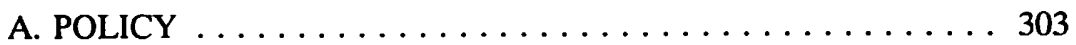

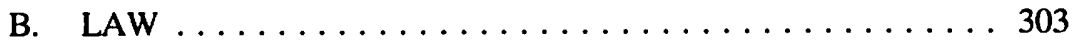

C. BUSINESS IMPLICATIONS $\ldots \ldots \ldots \ldots \ldots \ldots \ldots$

Barristers and Solicitors, Legal Departments, Shell Canada Ltd. and Mobil Oil Canada respectively. 


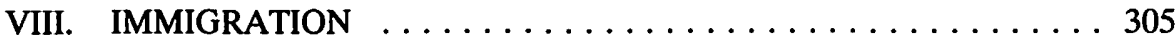

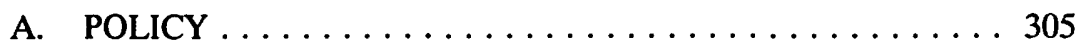

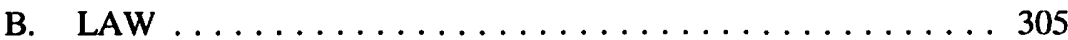

C. BUSINESS IMPLICATIONS $\ldots \ldots \ldots \ldots \ldots \ldots \ldots \ldots$

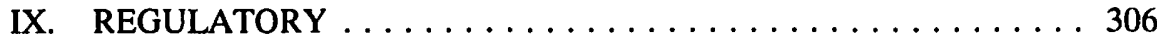

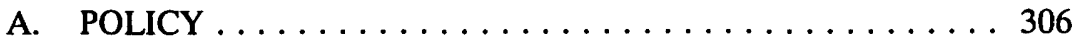

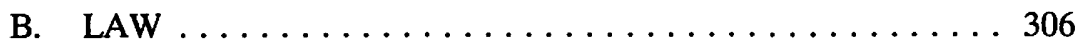

C. BUSINESS IMPLICATIONS $\ldots \ldots \ldots \ldots \ldots \ldots \ldots \ldots \ldots$

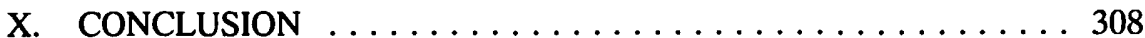

\section{INTRODUCTION}

The trading relationship between Canada and the United States is one of the world's largest bilateral commercial partnerings.

A significant portion of the value of the trade occurring is composed of the products and production of the energy industry of Western Canada. Canada is the largest supplier of natural gas to the United States.' It is the third largest supplier of crude oil and the second largest supplier of other petroleum products. ${ }^{2}$ Canada is also a significant source of the sulphur, petrochemicals and petroleum and petrochemical services imported into domestic American markets.

Slight fluctuations are occurring in Canada's position in relation to competing geographic sources of production, but the total dollar volume of all production from the energy industry is increasing. ${ }^{3}$ Approximately fifteen per cent of Alberta's gross domestic product is accounted for in export trade to the United States. ${ }^{4}$

The facility with which Canadian petroleum companies access and deal with American markets is becoming increasingly complex. ${ }^{5}$ The Free Trade Agreement ${ }^{6}$ deals with only some of the issues of trading into the United States. This article examines free trade as well as numerous other issues experienced by the energy industry in the bilateral trading context such as commercial law, trade law, taxation and regulatory regimes.

Some of the issues examined are vestiges of older regulatory philosophy and are causing inadvertent administrative inconvenience while others are protectionist policy

"Canada Third Largest Supplier of Petroleum to U.S. Last Year" Nickle's Daily Oil Bulletin (19 March 1993) at 1.

$3 \quad$ Ibid.; National Energy Board, "1992 Annual Report" (31 March 1993) at 2.

4 Alberta, Ministry of Energy, Untitled Presentation Materials, (10 February 1993).

5 The legislative context is also changing rapidly. This article was prepared in early June, 1993. Significantly, between the date of presentation and printing, side agreements have been struck under the North American Free Trade Agreement. [hereinafter FTA]. The treaty is implemented in Canada by the Canada-United States Free Trade Agreement Implementation Act, S.C. 1988, c. 65. 
tools. Some of the issues will continue to be constraints on trade while others will be removed over time as trade impediments.

Most of the selected areas of concern are outlined from three perspectives: policy, legal and business. The policy portions articulate the context in which the issues are handled. The legal portions briefly summarize the legal instruments by which the policy objectives are attained. The business portions outline considerations to assess the remaining constraints on the smooth operation of trade.

This article does not attempt to review Canadian laws except to the extent they are targeted at problems particular to trade into the United States' markets. While the authors summarize provisions of United States' laws they are not admitted to practice in any American jurisdictions.

\section{A. POLICY}

\section{FTA/NAFTA}

The North American Free Trade Agreement ${ }^{7}$ has embraced and built upon the FTA between the United States and Canada by requiring that Mexico accept key features such as the revocation of commodity tariffs ${ }^{8}$ and the limitation of both the application and proliferation of non-tariff barriers. ${ }^{9}$ Both the FTA and NAFTA have drawn upon the legal concepts and framework of the General Agreement on Tariffs and Trade ${ }^{10}$ to develop a trade liberalization arrangement the aim of which is to significantly reduce discriminatory trade barriers affecting the free flow of goods, services and investment in North America.

While the FTA and NAFTA may seem to be largely excise and dispute resolution arrangements, it is important to extract how they will affect the Canadian oil and gas industry.

Maintaining the United States as a preferred trading partner made it important to extend the FTA and to ensure Canada's place as a player in the multilateral NAFTA - an economic bloc which would be the world's largest free trade zone after the virtual elimination of tariffs and trade barriers in the next ten to fifteen years. The intent of the Canadian negotiators in the NAFTA was apparently not to establish great changes in access to the Canadian market but to create a substantive change in access to the Mexican market while sharing whatever new aspects of trade liberalization were to be offered up by the United States. Mexican States (14 December 1992) [hereinafter NAFTA]. The Agreement is implemented in Canada by the North American Free Trade Implementation Act, S.C. 1993, c. 44.

Ibid. Part Two, Chapter 3, Section B, Article 302.

Ibid. Part Two, Chapter 3, Section C, Article 309.

General Agreement on Tariffs and Trade (Geneva, October 30 1947; 55 UNTS 194) [hereinafter GATT]. 


\section{B. LAW}

The NAFTA maintains many of the positive aspects of the energy-specific provisions of the FTA such as the limited ability of a country to impose quantitative restrictions on the trade in a natural resource, ${ }^{11}$ prohibitions on minimum export or import price requirements ${ }^{12}$ and the obligation not to impose taxes or other charges on exports unless equally applied to domestically consumed energy. ${ }^{13}$ It is important to note that other beneficial provisions of the FTA remain unaffected or are included in the NAFTA such as the removal of tariffs and fees like customs user fees. ${ }^{14}$

Mexico has agreed in the NAFTA to allow investment in limited varieties of non-utility power generation and gas-fired electrical cogeneration, petrochemicals and fertilizers. ${ }^{15}$ However, one of the negative aspects of the NAFTA relates to its failure to obtain Mexico's agreement to allow foreign investment in its petroleum exploration, production, refining and most of its petrochemical industries. Mexico has also been unwilling to agree to be bound by the provision ensuring that any export restrictions do not reduce the proportion of exports to total supply when compared to the proportion existing in the recent historical timeframe.

The NAFTA's improvements over the FTA are numerous including a firmer basis from which Canadian gas exporters may challenge discriminatory actions of United States' energy regulators. This should ensure that long-term contracts are only terminated with proper notice and compensation. ${ }^{16}$ The NAFTA also contains various broad policy provisions like the right to invest, ${ }^{17}$ protection against expropriation, ${ }^{18}$ repatriation of profits, ${ }^{19}$ basic common rules on intellectual property ${ }^{20}$ and competition policy. ${ }^{21}$ The protection of intellectual property rights such as trademarks, copyrights and trade secrets has been adopted from the current GATT draft. It seeks to protect these rights on the basis of national treatment including enforcement provisions such as injunctions, damages and general due process rights. ${ }^{22}$

In the event that a client is a consultant or has the potential to sell its expertise or technology in a consulting role, the NAFTA contains provisions which will facilitate the licensing of legal consultants and other professionals like engineers and specialists in the areas of oil and gas, computers, the environment and telecommunications. ${ }^{23}$ Citizenship

Supra note 7, Part Two, Chapter 6, Article 603, Paragraph 2 and Article 605.

Ibid.

Ibid. Part Two, Chapter 6, Article 604.

FTA, supra note 6, Part Two, Chapter 4, Article 403; NAFTA, Part Two, Chapter 3, Article 310.

NAFTA, supra, note 7, Part Two, Chapter 6, Annex 602.3.

Ibid. Part Two, Chapter 6, Article 606.

Ibid. Part Five, Chapter 11, Article 1102.

Ibid. Part Five, Chapter 11, Article 1110.

Ibid. Part Five, Chapter 11, Article 1109.

Ibid. Part Six, Chapter 17.

Ibid. Part Five, Chapter 15.

Ibid. Part Six, Chapter 17.

Ibid. Part Five, Chapter 16. 
and residency requirements are to be removed as conditions of licensing and certification of service providers within two years. However, service providers will still be subject to the host country's standards for competency, training and experience.

\section{BUSINESS IMPLICATIONS}

The commercial impact of the NAFTA on the Canadian petroleum industry may come about in a number of possible ways now that Mexico is included in the trade equation. On the production side, there are additional potential opportunities for exporters of sulphur, liquid petroleum gases and non-crude oil products such as bitumen, asphalt, lubricating oils, greases and waxes. The natural gas industry is expected to benefit from an improved supply-demand balance in the North American gas market in the event of increased gas consumption and the routing of United States gas to Mexican end-users.

It is debatable at present whether a greater amount of foreign direct investment will flow into Mexico and cause its economy to grow faster at Canada's expense. The Canadian petroleum industry has and will continue to depend on considerable infusions of domestic and foreign capital for its operations so the eventual geographic placement of that capital will be of intense interest as the NAFTA takes effect and evolves. Will investors always be swayed by the presently low wages and lower standards of environmental controls in Mexico when compared to Canada's higher productivity, lower transportation costs, quality control and advanced skills and technology? ${ }^{24}$ In addition to products sales, opening the oil services sector in Mexico to North American competition should increase demand for Alberta based engineering and service companies.

There will continue to be alternatives to the domestic judicial systems of each country due to the NAFTA's reliance on independent review panels for determination of discriminatory trade restrictions, anti-dumping and countervailing duty matters. One may see no direct or immediate effect by the NAFTA on a client's business, but it will be important to know a client's rights in the event one must give advice on trade and investment opportunities or appeal actions of the other countries which adversely affect the energy industry.

There may well be a minimal impact upon Canadian oil and gas traders on a day to day basis but the energy provisions of the FTA and NAFTA, including the prospect of a more stable regulatory environment, will continue to share long-term strategies for North American export and investment markets.

\section{COMMERCIAL LAW}

\section{A. POLICY}

The body of commercial law which has developed in the United States is dauntingly large, varied and complex. The size of the United States' economy, the scale of the 
marketplace, its world-wide trading connections and the lengthy evolution of the free market system (the writers presume to use that phrase despite the state of regulation which exists) have all contributed to the sophisticated and often Byzantine nature of commercial laws. Whether one chooses to retain United States' legal expertise it is worthwhile for Canadian counsel to carefully consider some general issues confronting any client contemplating or already doing business in that jurisdiction.

The following topics are a selection of commercial law issues representing an abbreviated check-list for the counsel advising an energy and petroleum products marketing company who may be looking for issues to form the initial focus of their deliberations.

\section{B. LAW}

\section{Uniform Commercial Code ${ }^{25}$}

It should not come as a surprise to Canadian lawyers who must practice within a federal state that the legal obligations and standards that apply to commercial transactions in the United States were and are still found largely in individual state laws. The incredibly complex structure of United States' commercial laws caused by conflicting state laws was the impetus for an umbrella federal uniform commercial law statute known as the Uniform Commercial Code. While not as comprehensive or complete as a civil code, it does represent the principal statutory source of United States' law in areas such as sales of goods, secured transactions and credit instruments. Even though it is almost universal in its adoption (the exception being Louisiana), Canadian counsel must ultimately be aware that trading with a particular state requires a review of its individual laws since variations of the official text have been enacted in each state. In addition, the courts of each state have interpreted the U.C.C. differently and each state's supplemental laws (e.g. principal and agent, fraud, bankruptcy and equity) must all be taken into account in the determination of a particular issue.

The U.C.C. is flexible to the extent that the parties to a transaction are free to insert a choice of law provision (failing which the U.C.C. may apply) and vary its other provisions provided that basic principles like good faith, diligence, reasonableness and care in dealings are all observed. ${ }^{26}$ The parties may not be able to disclaim or contract out of the aforementioned principles but they are free to set the standards for judging compliance as long as they do not defeat the overall intent of the U.C.C. ${ }^{27}$ 
One of the interesting implications of the U.C.C. to international traders is that it has modified common law principles around formation of contract to have legal requirements reflect actual business practice. ${ }^{28}$ The result is that the actions of the parties may indicate an intention to be bound and be characterized as the basis for a contract. In other words, parties can express an agreement in writing, orally or by conduct without actually agreeing on contractual elements like price, time of delivery or method of payment, since the U.C.C. will fill in the gaps so long as the parties can agree on an arrangement for the purchase and sale of a known quantity of identifiable or describable goods. This is a warning to lawyers drafting statements or letters of intent that great care should be taken to clearly indicate a party's intention not to be bound or at least agreement to be bound only upon the occurrence of a defined event or the conclusion of an agreement on all material terms.

\section{Products Liability}

In a straightforward trading arrangement, all that a company may want to do is sell its goods to a buyer in the United States. While the company may initially consider the sale to be over once title and possession have passed, the vendor company has just introduced its product into the stream of United States' commerce and is potentially liable for injury or loss to anyone who is a consumer or user of the product. The "products liability" field is, in no uncertain terms, a growing legal industry in the United States, and the damage awards and settlements can be substantial. Grounds for recovery presently allow a plaintiff to frame an action in one or all of negligence, breach of warranty or strict liability in tort. There are additionally a host of federal and state statutes regulating specific types of substances or activities. ${ }^{29}$

The United States' jurisdictions which have adopted strict liability in tort have placed a product vendor in a position where fault and breach of warranty are not issues (disclaimers being ineffective) required as proof of liability. It is true, however, that a defendant will not incur absolute liability in the event of an injury from the use of its product since the plaintiff must show that the product which was the proximate cause of the injury was defective when it left the defendant's control. ${ }^{30}$ The issue of product liability does not just exist for vendors in the consuming marketplace since all persons in the commercial chain such as distributors and re-sellers may be liable. As an aside, New York law represents a slightly different twist in that contributory negligence, while not a defence, can work to reduce the damages which may be awarded. ${ }^{31}$

Liability for breach of warranty whether express or implied in instances of merchantability or fitness for a particular purpose has, in most United States' jurisdictions,

Ibid. § 2-204(3).

See for example the Consumer Product Safety Act, 15 U.S.C. § 2075; The Federal Hazardous Substances Act, 15 U.S.C. § 1261-1274; and The Toxic Substances Control Act, 15 U.S.C. § 26012629.

Greenman v. Yuba Power Products, Inc., 59 Cal. 2d 57, 27 Cal. Rptr. 697, 377 P.2d 897 (1962);

Kerr v. Corning Glass Works, 169 N.W.2d 587 (Minn 1969).

C.P.L.R. § 1411 . 
set aside the requirement for privity and has extended warranties to anyone who could reasonably be anticipated to use or in any way deal with the product. ${ }^{32}$ Effective disclaimers must be very specific and conspicuous since they are strictly construed against the manufacturer or vendor. ${ }^{33}$

While liability for negligence in American law is not significantly different from the theoretical basis to which Canadian counsel are accustomed, it imposes a further standard of care which requires that manufacturers conform as closely as possible to available state of the art methodologies. ${ }^{34}$ Manufacturers are also under a duty to adequately warn users of potential dangerous characteristics of their products and provide appropriate instructions respecting their use. ${ }^{35}$ The crucial element to note in this area is that the variety of individuals to whom the manufacturer is liable continues to grow. It encompasses all those to whom the manufacturer owes a duty of reasonable care to prevent the entry of a dangerous and defective product into the stream of commerce.

The central business implication of this area is certainly that of damages. Damage awards for personal injury and property damage can be extremely large, and liability insurance may be an essential business tool for particular product sales. Damage actions may be brought for personal injury such as pain and suffering, loss of earning, disability, wrongful death; property damage; commercial losses (the availability of pure economic loss varies among jurisdictions); and punitive damages. ${ }^{36}$

\section{International Sale of Goods}

Although it may appear that all of the issues in Canadian and United States' laws which may impact on a client's business transaction have been identified, the provisions of an international convention may also need to be addressed. Approximately 40 countries with very different legal systems such as the United States, Syria, China, France and Canada have now adopted the United Nations Convention on Contracts for the International Sale of Goods ("CISG"). ${ }^{37}$ The general application of the CISG affects agreements for the sale of goods between parties whose places of business are located in countries that have adopted the CISG. It may also apply where only one party to the agreement has its place of business in an adopting country.

Many trading companies have concluded that the CISG is too uncertain in types of international commerce which are carried on in jurisdictions where legal rules are well established and contractual principles and phraseology are well defined and understood.

Green v. Volkswagen of America Inc., 485 F.2d 430 (6th Cir, 1973).

U.C.C. § 1-201(10); Henningsen v. Bloomfield Motors, Inc., 32 N.J. 358, 161 A.2d 69 (1960).

Northwest Airlines v. Glenn L. Martin Co., 224 F.2d 120 (6th Cir. [Ohio] 1955).

Tuscon Industries, Inc. v. Schwartz, 15 Ariz. App. 166, 487 P.2d 12 (1971); Moran v. Faberge, Inc., 273 Md. 538, 332 A.2d 11 (1975).

The United States Supreme Court has again recently declined to limit punitive damages: TXO Production Corp. vs. Alliance Resources Corp. 113 S. Ct. 2711, 125 L. Ed. 2d 366 (U.S.S.C. decision announced June 25, 1993).

Implemented in Canada by the International Sale of Goods Contracts Convention Act, S.C. 1991, c. 13, also R.S.C. 1985, c. I-20.4 [hereinafter known as CISG]. 
Each business may have its own reasons for choosing to have the CISG apply to its transactions, however, a great number of companies have chosen to avoid its application (characterising it as a "buyer's convention") by expressly excluding it in a choice of law clause.

The following examples of the CISG's provisions illustrate why its application may be a cause for concern or outright rejection:

(i) the CISG does not cover the validity of the contract, transfer of title, liability for damage caused by the goods sold or dispute resolution; ${ }^{38}$

(ii) a contract need not be concluded or evidenced in writing and, since it can be proved by any means, including parol evidence, certain provisions are binding on the parties by their own usage and practice as well as any usage they ought to have known to be widely accepted in international trade; $;^{39}$

(iii) all previous negotiations, practices, usages and all prior and subsequent statements made by the parties may be utilized by an adjudicator in ascertaining the parties' contractual intent; ${ }^{40}$

(iv) a reply to an offer which contains additional or different terms which do not materially alter the terms of the offer may constitute a valid binding acceptance;

(v) the CISG contemplates the conclusion of a contract without a provision for price and will infer a price generally charged at the time for such goods in the course of that trade; $;^{42}$ and

(vi) damages for breach of contract are based on a wider "possible consequence" test instead of the "probable consequence" test applied in this jurisdiction. ${ }^{43}$

While it is the opinion of many lawyers that the CISG may represent an unacceptable set of codified commercial laws in the particular circumstances of today's international trade, businesses may well adapt to it and find it more acceptable over time. Counsel for the seller of goods needs to carefully examine every international agreement to determine the implications of not excluding the CISG's application. 


\section{Miscellaneous Statutes}

The creditworthiness of a trader's customers, business associates, joint venturers and partners takes on a whole new importance if one anticipates the time, effort and cost of evaluating and subjecting oneself to the myriad of substantive laws, procedural rules, collateral legislation, the federal bankruptcy court system and the inter-play of jurisdictions and venues. A lesser but not unimportant aspect of bankruptcy laws concerns the reorganization provisions of Chapter 11 of Title 11 of the United States' Code. Like the provisions of the new Canadian bankruptcy legislation, ${ }^{44}$ a petition under Chapter 11 instigates a whole series of procedures, altered legal rights and priorities that impact on the trader's original business transaction.

In the event that a trader is considering a transaction which involves the trans-shipment of a commodity through the United States or the export of a commodity from the United States, the provisions of the Export Administration Act of $1979^{45}$ may be applicable depending on the country of destination. This statute, which was enacted to further national security and the protection of the domestic economy, amounts to a detailed system of licensing and lists of commodities which may not be exported to particular countries including the export of crude oil and refined oil products.

\section{BUSINESS IMPLICATIONS}

The commercial law topics set out in this paper are certainly not comprehensive with respect to all the issues one must consider in structuring a transaction with a party in the United States. At a minimum, these topics represent a good initial check-list, and at best they may have stimulated you to consider how to satisfy yourself that all relevant issues have been thoughtfully reviewed prior to approving your client's entry into the United States' "stream of commerce."

\section{JURISDICTION}

\section{A. POLICY}

In addition to being concerned with identifying issues which are central to counselling a client respecting how it may trade with United States' commercial entities, a decision may be required which focuses upon whether the client should be doing business in the United States, and, if so, whether all the risks have been weighed in deciding upon the proper and effective vehicle which meets that client's needs. One must weigh the implications of doing business in a way that will draw a trader within the jurisdiction of the American judicial, taxation and securities systems. Initially, a transaction may make perfect logistical and financial sense in terms of where title may pass, who will transport the product and where the client intends to execute the formal agreement. However, it is likely that a trader will be sensitive about the applicable tax regime, legal jurisdiction for 
the resolution of disputes and the enforceability of its insurance. As a result, it may be necessary to restructure the transaction and business entities which will be the contracting parties.

Trading directly in the United States could cause a trader to be viewed and assessed as conducting business in that jurisdiction.

\section{B. LAW}

Once legal counsel has provided advice concerning the risks which United States' jurisdiction poses to a Canadian business, the commercial client will need to know the various methods of trading with, as opposed to in, the United States.

Assuming a trader is not in a position to do business through a resident United States' subsidiary, there is a structural way to approach direct sales into the United States which will help to avoid its business activities being assessed as constituting a permanent establishment for tax purposes and minimize the risk of creating a nexus to United States' jurisdictions. The following is a comprehensive though not exhaustive list of activities and methodologies for carrying on business outside the jurisdiction:

(i) do not have offices, warehouses or terminals in the United States;

(ii) do not have employees or full time business agents and sales representatives in the United States;

(iii) do not deliver products within the United States or provide for title to transfer to the customer in the United States;

(iv) title and risk should always pass in Canada or at the border;

(v) do not maintain inventory other than in-transit inventory in the United States or store product on a consignment basis as even instantaneous swaps could be construed as doing business in the United States;

(vi) while soliciting business in the United States, agreements should be accepted, completed and executed in Canada and do not give any American agent or related company the authority to bind the Canadian company;

(vii) do not acquire products or assets in the United States for resale there;

(viii) provide for the applicability of Canadian laws in the contract;

(ix) do not bank in the United States;

(x) keep necessary business trips to a minimum; 
(xi) shipping and customs documents should not show the Canadian business as the importer; and

(xii) do not contract for transportation or other services provided in the United States.

In some cases a Canadian business may decide to trade with and in the United States through a resident American subsidiary company. This particular subsidiary should be the entity which is subject to the United States' judicial and taxation systems where it does business and is resident. In order that the subsidiary is viewed as a bona fide United States' corporation separate and distinct from its Canadian parent, deliberate care must be taken to avoid it being deemed merely an agent of the parent company. United States' authorities test a subsidiary's independence by numerous criteria and tests, including:

(i) the degree to which business is actually carried on by the Canadian parent in the name of the United States' subsidiary;

(ii) whether the employees of the Canadian parent treat the United States' subsidiary as a mere department of that parent;

(iii) the degree to which the Canadian parent observes and respects the internal corporate formalities of the subsidiary; and

(iv) whether the Canadian parent controls the financial, personnel and marketing and operating policies of the United States' subsidiary.

At a minimum, one can mitigate the risk of a United States' subsidiary being deemed an agent of the Canadian parent and subjecting the parent company to United States' jurisdiction by observing the following rules:

(i) all commercial transactions between the parent and subsidiary should be evidenced by standard industry documentation and be at arm's length;

(ii) the majority of the subsidiary's directors must be United States' residents and the director's meetings should all take place in the United States;

(iii) the subsidiary's directors are free to seek advice from the parent company but must not exercise their authority as a "rubber stamp";

(iv) management, operational and marketing advice and assistance may be obtained from the parent company only through written requests pursuant to service agreements which provide for bona fide payment of consideration;

(v) if the subsidiary is an integral part of a commercial transaction it must receive fair value for its role as importer, purchaser, broker or trans-shipper;

(vi) all financial books, records and minute books should be kept at the United States registered head office of the subsidiary; 
(vii) ensure that the subsidiary is adequately staffed with knowledgeable personnel and officers who are not employees of the parent company; and

(viii) the subsidiary should maintain its own bank accounts and telephone directory listings.

\section{BUSINESS IMPLICATIONS}

The United States' judicial and tax system are matters for commercial counsel to take into account when considering a transaction with a United States' party or the sale of a product or commodity into or within the United States. The prospect of litigation in the United States, whether involving issues stemming from breach of contract, tort, environmental damage or quasi-criminal charges, is a serious implication indeed.

\section{TRADE LAW}

\section{A. POLICY}

A fundamental premise of the European Economic Community as it developed and expanded was the harmonization of trade and financial laws. The need for relatively complete rationalization of the laws in Europe was recognized as an integral component of a free trade zone and has been an ongoing objective of the European Community.

The approach of Canada and the United States through the FTA and NAFTA has been somewhat similar, starting with customs matters. Whereas the European Community expanded the trade law harmonization process from the initial customs tariff agreements in the Treaty of Paris, ${ }^{46}$ there are no commitments on collateral trade issues beyond the provisions of the explicit test of the FTA and the NAFTA.

Ultimate harmonization of trade laws is essential to remove barriers between markets. Customs tariffs are only one of the two most direct means of influencing market access. ${ }^{47}$ Other indirect policy tools available to governments which affect trade include:

(i) subsidies,

(ii) standards,

(iii) trade permission requirements, and

(iv) administrative impediments.

47 The other being a system of import and export quotas. Quotas are addressed in the GATT, as well as in portions of the FTA and NAFTA. 
Examples of the current application of each of these policy tools in a manner which is affecting the behaviour of Canadian exporters include: countervailing duties, dumping tariffs, anti-trust concerns and customs administration respectively.

While a lengthy process of trade law harmonization is contemplated in both the FTA and the NAFTA, there is no firm timetable to reconcile problems created. The United States insisted on retaining the rights to impose dumping tariffs, and countervailing tariffs and they are retained in accordance with express provisions of the FTA. ${ }^{48}$

\section{B. LAW}

\section{Countervailing Duties}

Countervailing duties are special customs duties imposed on imports in an amount designed to offset the value of subsidies given by a government as an incentive to manufacture or export a product. The duty approximates the value of the subsidy so that the cost of the product in the United States is equal to the fair value of production less the subsidy plus the duty. This nets out approximately.

The theory behind countervailing duties is that domestic suppliers of a product who base their prices on a cost of production are allowed to compete fairly against foreign sources who have reduced costs of production because of foreign subsidy. American countervailing duty provisions are found in the Trade Agreements Act of $1979^{49}$ and the Tariff Act of $1930,{ }^{50}$ both administered by the International Trade Commission of the Department of Commerce.

\section{Dumping}

Dumping is traditionally viewed as the export of goods at prices lower than those the exporter charges to home market or third country buyers. If home market or third country sales are found to be priced below the cost of production, no foreign market value will be deemed to exist and a value will be constructed. The amount of duty as determined by the United States Treasury Department is intended to equalize the differences between foreign market value or instructive cost and the export price into the United States. Thus, anti-dumping duties are special customs duties imposed on imports which offset the value of cross-subsidization experienced from other geographic markets by the producers or exporters of the goods.

Authority for United States' anti-dumping duties now arise in provisions of the Trade Agreements Act of $1979 .^{51}$ 


\section{Anti-trust}

There are two aspects of the Canadian Competition $\mathrm{Act}^{52}$ which have extra-territorial effect. First, conspiracies or combinations are permitted in Canada relating to the export of goods from Canada where there is no reduction in volume of exports and Canadian competitors or markets are not affected. ${ }^{53}$ Second, it is an offence under the Act to implement a directive or instruction from someone outside Canada in order to give effect to an agreement that if entered into in Canada would violate the conspiracy provisions of the Act. ${ }^{54}$

The provisions of the various anti-trust statutes apply to any foreign commerce having a direct, substantial and reasonably foreseeable effect on American commercial interests. ${ }^{55}$ Conduct occurring in Canada relating to goods and services which ultimately reach the United States will be subject to the provisions of the anti-trust laws.

In the United States the Sherman $A c t^{56}$ prohibits contracts, combinations or conspiracies that unreasonably restrain trade. Price fixing, market allocation, resale price maintenance, bid rigging, agreements to limit production and boycotts are all per se offenses. The Clayton $\mathrm{Act}^{57}$ prohibits arrangements such as mergers which tend to substantially lessen competition or create a monopoly. The Robinson-Patman Act, ${ }^{58}$ which amends the Clayton Act, prohibits price discrimination. Its provisions are intended to protect small businesses. It is not designed to promote efficiency or consumer welfare. The Federal Trade Commission Act $t^{9}$ prohibits unfair methods of competition.

United States' anti-trust laws resemble the Canadian laws with the exception that they have a greater number of per se offenses. Parties trading into the United States should be aware that conduct which is legal in Canada as not "unduly affecting competition" is illegal in the United States because of the per se nature of the offence.

Under NAFTA, a trilateral committee is to consider the relationship between competition laws and trade policy, ${ }^{60}$ and on a practical level each country is to adopt or maintain measures against anti-competitive business practices. Government owned or controlled enterprises are to act consistently with that country's NAFTA obligations. When trading in their goods or services, federal monopolies must follow commercial considerations and not discriminate against other countries' goods and services. In addition, monopolies are to be prevented from using their positions to engage in anticompetitive practices in non-monopoly markets in their own countries.

R.S.C. 1985 , c. C-23.

Ibid. section 32(5).

Ibid. section 32.1.

United States v. Aluminum Company of America, 148 F.2d 416 (2d Cir. 1945).

15 U.S.C. $\S 1-7$ (1982).

Ibid. § 12-27 (1982); 29 U.S.C. § 53 (1982).

lbid. § 13a-13b, 21a.

Ibid. § 41-58.

NAFTA, supra note 7, Part Five, Chapter 15, Article 1504. 


\section{Customs Tariffs}

There is no duty payable on the importation of most petroleum products or by-products into the United States. Importers must however file United States' Customs Service forms alerting the Department of Commerce to the quantity and value of imports. ${ }^{61}$ With that form a modest Merchandise Processing Fee is payable.

If filings and payments are not made then penalties based on multiples of the value of revenue not received by the Customs Service are payable by the party which it has determined is liable for making filing and payment.

In pipeline matters, there are few means by which the Customs Service can access the information it requires to determine who is liable to pay tax and the amount for which such parties are liable. The pipeline companies are providing limited information about possession of transportation rights. If better evidence is not available, the Customs Service resorts to export figures published by the National Energy Board to attempt to determine the liability for filing. Curiously, they accept National Energy Board information in preference to Department of Energy import authorization information.

The practical result of the use of Canadian data to enforce Customs Service compliance is that the Customs Service is forcing customs compliance from Canadian exporters as opposed to American importers. The Merchandise Processing Fee is being phased down and under the FTA will be eliminated by January $1,1994 .^{62}$

\section{BUSINESS IMPLICATIONS}

A proposed entrant into the American market should undertake an audit of corporate and industry practice and structure to determine and manage the issues which may arise as a result of trade law disharmony.

The structure of the oil and gas industry is not something which any individual corporation can change or perhaps even influence in the short term. Accepting given structures, relationships and legislation as constraints upon the way Canadian businesses can operate, and recognizing that United States' legislation was often prepared in a very different context results in situations where accepted or required industry practice is a violation of legislated requirements.

Existing trade into the market should perhaps factor in the costs of legal resistance of administrative action, recognizing that the opposing party is often the United States' government. The costs of failing to resist could include the creation of a barrier to reentry into the market or extra-territorial enforcement of United States' laws. 
Undue administrative enforcement of irreconcilable differences in trade laws or alleged offences arising from industry structures are often instigated as short term market protection mechanisms.

\section{TAXATION}

\section{A. POLICY}

Canada's corporate income tax system is premised on the taxation of Canadian sourced income. ${ }^{63}$ Provincial taxation statutes parallel the federal taxation system to various degrees and result in a general harmony within Canadian jurisdiction regarding liability for taxation.

The federal tax system of the United States is based on residency and source of income. ${ }^{64}$ State income taxation regimes vary from non existent to systems based on residency or source, or arbitrary systems allocating financial income based on business statistics or transactions. There is substantial disharmony among federal and state taxes within the United States. Various states have franchise taxes which take the form of capital or property taxes. ${ }^{65}$

Both Canada and the United States attempt to avoid the double taxation of taxpayers through use of foreign tax credits. Simply, these are credits against domestic income tax for the amount of foreign income tax paid.

While the foreign tax credits offer some relief, more complex situations which could lead to double taxation in federal taxing statutes are addressed in the Canada-United States' Tax Treaty. ${ }^{60}$

\section{B. LAW}

Corporations engaged in business in the United States in a taxation year must file an income tax return even though no locally sourced income is incurred or the income is sheltered by tax treaty or provision of the Code. The concept of being engaged in business has evolved in case law. Three events are specified by statute:

(i) performing personal services;

(ii) trading in securities; and however because foreign sourced income receives a tax credit and special treatment under treaty, the result is comparable to source based taxation. 
(iii) trading in commodities. ${ }^{67}$

In other cases the question is determined in both a qualitative and quantitative manner. If there is any sort of active role taken in the generation of American sourced income, particularly in large amounts, then there is a likelihood of being found to be engaged in a trade or business.

While the immediately following paragraphs refer to state taxation, local taxation also exists. Local authorities, in the same manner as state authorities, are imposing local sales and income taxes. Although such taxes are not specifically referred to, they have considerations similar to those of state taxes. ${ }^{68}$

State-imposed franchise taxes ${ }^{69}$ on businesses are based on the property or wealth of a business within the state. There is also jurisdiction to tax sales, income or property. Business income taxes are normally imposed at low rates. Such taxes are valid, even if imposed on the results of interstate commerce, if they are applied to goods having a nexus to the state, are fairly apportioned, do not discriminate against interstate commerce and relate to benefits provided by the state. ${ }^{70}$

There is no single test of nexus in the taxing statutes of the various states. The type of test depends on the taxing statute as well as upon the type of tax imposed.

The liability for taxation, or nexus, is often coincident with the requirement to apply for a certificate of authority within the state. ${ }^{71}$ If a corporation is required to qualify but does not, it may be subject to a variety of penalties including back taxes and fees, monetary fines or criminal penalty.

The types of activity which could create nexus vary considerably, but they include:

(i) sales through telephone or mail in conjunction with offices or inventory kept in the state;

(ii) sales through independent contractors who keep offices in the state;

(iii) regular solicitation of orders by salesmen within the state;

(iv) inventory in the state from which goods are delivered by common carrier;

(v) offices, salesmen, cars or telephone reception facilities within the state;

(vi) qualifying to do business within the state;

Internal Revenue Code $\$ 864$ (b).

See generally Spires, supra note 65 at $\$ 11.01$ [3].

lbid.

California State Board of Equalization v. Sierra Summit, Inc., 109 S. Ct. 228 (1989).

For example, Texas and Washington. 
(vii) retaining security interest in goods sold;

(viii) acceptance of orders in the state; and

(ix) ancillary sales activity including credit investigations, C.O.D. shipments and service calls. ${ }^{72}$

"Unitary tax" jurisdictions ${ }^{73}$ measure income earned by multi-jurisdictional corporations by allocating a portion of the total income earned by the multinational units within the ownership of the taxpaying corporation to that state. The justification is that unitary tax prevents the funnelling of profits to foreign subsidiaries.

Double taxation is not only possible, but it has been recognized as actually existing. ${ }^{74}$ Nevertheless the Supreme Court of the United States upheld the right of states to impose unitary based taxes. ${ }^{75}$ The manner in which a unitary tax is calculated within a jurisdiction can create a degree of unfairness. For example there is precedent for the use of payroll within a state as a percentage of total worldwide payroll applied to worldwide income to determine a state's tax base. ${ }^{76}$ Recognizing that salaries in the United States are among the highest in the world, there is a resulting bias toward expanding the tax base within the state.

A "permanent establishment" is defined in Article V of the Canada/United States Income Tax Convention. ${ }^{7}$ It includes:

(i) an office, or

(ii) an oil or gas well, or

(iii) a person in a state with authority to conclude contracts in the name of the resident,

but does not include:

(i) storage facilities, or

(ii) maintenance of inventory. ${ }^{78}$

The only limitations on a states' ability to impose an income is in the Foreign Commerce and Due Process clauses of the U.S. Constitution.

For example, California, New Hampshire, North Dakota and Oregon, although California has retreated from applying the tax.

Japan Lines Lid. v. County of Los Angeles, 441 U.S. 434, 99 S. Ct. 1813, 60 L. Ed.2d 336 (1979). There are numerous cases on point, but Container Corporation of America v. Franchise Tax Board, 463 U.S. 159, 103 S. Ct. 2933, 77 L. Ed.2d 545 (1983) [hereinafter Container Corporation] occurred after the Japan Lines decision.

For example, California. This was upheld in the Container Corporation case, ibid.

Washington, September 26, 1980. Implemented by S.C. 1984 c. 20.

Ibid. Article V, paragraph 6. 
A permanent establishment is not deemed to be created by the presence of a broker or independent agent. Note the overlap but not necessarily the coincidence between the definitions of "nexus" and "permanent establishment."

The Canada/United States' Tax Treaty exempts industrial or commercial profits from tax if the Canadian taxpayer has no permanent establishment in the United States. ${ }^{79}$

\section{BUSINESS IMPLICATIONS}

A practical problem attached to the multiplicity of taxing jurisdictions in the United States lies in the administrative inconvenience of assuring full compliance with taxing and business registration requirements. Possibility of double taxation diminishes with the administrative burden attached to continuous monitoring of assets and activity within each state. The trader also faces the onerous consequences of complying with all applicable federal, state and local tax rules, filing of returns and audits of their books of account.

Another consideration is the ability to plan business activity around the incidence of state taxation. The location of facilities can give rise to the incidence of income tax and property or franchise tax, or may create an obligation to compute and pay unitary based tax. The after tax income resulting from a sale can vary according to the location of title transfer. The routing of delivery of the product can change according to taxes imposed on the transportation facility.

\section{TRANSPORTATION}

\section{A. POLICY}

Any trading agreement, either directly or indirectly, will contain provisions concerning the physical transfer of possession of a product to and from the point of delivery to its intended destination.

Domestic and applicable international regulation will apply to all manner of transportation. From a policy perspective, these regulations address general environmental concerns, and protect workers who handle the product and particular members of the public who may be affected by its discharge.

Matters of pipeline transportation are dealt with in the section of this article entitled "Regulatory."

\section{B. LAW}

The legal aspects of marine transportation of petroleum products and hazardous goods in general have been a fertile ground for lawyers and legislators alike since the occurrence of recent unfortunate incidents like the oil spills from the Amoco Cadiz and the Exxon 
Valdez. Trading into and within American waters now necessitates assuring oneself that a carrier is a member of the International Marine Organization and is covered by the Organization's minimum legal requirements relating to safety and environmental protection. Conventions such as the 1969 Civil Liability Convention, the 1971 Fund Convention and their later protocols provide for oil pollution coverage available to tanker owners for strict liability damages resulting from such spills. A trader's risk management department or insurance broker will have to provide advice concerning the availability and necessity of coverage under voluntary insurance schemes such as TOVALOP (for tanker owners) and CRISTAL (for cargo owners) to help ensure adequate pollution compensation for third party damage. Many traders require all ships they charter to be entered into TOVALOP and maintain pollution liability coverage to its full extent as well as carrying a certain level of protection and liability insurance by being a member of a P\&I Club. In addition, many traders inspect all ships under contract to ensure they comply with or exceed international standards, especially those concerning protection of the environment.

The Oil Pollution Act of $1990,{ }^{80}$ while it does not deal with cargo owner or charterer liability, requires the introduction of double hulls on all tanker vessels entering United States' territorial waters by 2015 and also requires that all vessels ordered after August 1990 must have double hulls for entry into those waters. In a similar move, there is a MARPOL International Convention which now specifies that all new tankers built after July 1995 must have a double hull and limits the life of all existing tankers without double hulls to thirty years.

Eleven states in the United States now render cargo owners liable for the acts and omissions of their carriers who are destined for facilities within their jurisdictions from the time such carriers enter state waters until the time they leave. With liabilities as unlimited as those provided for in $O P A 90$, it also makes sense to require that the carrier and receiving or loading facility of the product is a member of the Marine Spill Response Corporation. This will ensure that your client obtains the benefit of this nation-wide provider of equipment and services for the containment and clean-up of discharges into the marine and coastal environment. In addition, each state has its own laws which can be more onerous than OPA90's provisions, and can override those of OPA90 with federal agreement.

In the area of surface transportation such as rail-cars and trucks, the party contracting for transportation services or the owner or lessee of such vehicles within the United States will be subject to the American legal and regulatory system which will apply in the event of injury to third parties or the environment caused by the vehicle or its contents. In the event of injury caused by the release of a product during transport, federal and state legisiation provides for a host of obligations and liabilities which will include reporting, emergency response clean-up and general public liability for damages. The obligations and liabilities to be applied are determined according to the status of the client as the owner 
of the goods or the supplier and owner or lessee of the vehicle. ${ }^{81}$ Also, as in Canada, the owner or lessee of the transporting vehicle may be subject to obligations respecting the packaging, labelling, classification and shipping documentation required to transport hazardous materials. ${ }^{82}$

Regardless of obligations and liabilities imposed by statute, common law claims in negligence relating to the transport of dangerous or hazardous goods are also possible in case of accidental release involving a trader's goods or vehicles. Certain federal laws, however, do contain pre-emption provisions which provide defences to state statutory or common law causes of action respecting regulated activities such as the transport of hazardous materials. ${ }^{83}$

\section{BUSINESS IMPLICATIONS}

The effect of regulations respecting the establishment of rigorous enforcement of structural and operating standards for tankage vessels has been to place the charterer of vessels on notice as to the kind of vessel and operator which should be used in the future to transport its goods in United States' waters.

Federal and state legislators have put in place a myriad of statutes and associated regulations imposing duties and obligations on product owners and transporters. These must be carefully reviewed in order to decide whether the risks of transporting goods in the United States outweigh any potential benefits after taking into account all available safety procedures and insurance coverages.

\section{IMMIGRATION}

\section{A. POLICY}

The ability of a supplier to freely access a market place in order to sell, distribute and service those markets is essential. The free movement of persons across the border is therefore addressed in the FTA and the NAFTA.

\section{B. LAW}

Immigration regulations have been adopted which permit the reciprocal temporary entry of citizens of Canada to both Mexico and the United States. ${ }^{84}$

See for example Hazardous Materials Transportation Act, 49 U.S.C. $\$ 1801$ et seq; Federal Rail Safety Act, 45 U.S.C.A. \$ 421 et seq; The Comprehensive Environmental Response, Compensation and Liability Act, 42 U.S.C. \$ 9601 et seq.

$82 \quad$ Transportation of Dangerous Goods Act, R.S.C. 1985, c. T-19.

83 Federal Rail Safety Act, supra note 81, § 434; Hazardous Materials Transportation Act, supra note $81, \S 1804$.

8) NAFTA, supra note 7, Part Five, Chapter 16. 
Temporary entry is granted to "business visitors" engaged in activities relating to the marketing, sales, distribution after sales service and other general services. General services include management, supervisor and financial services engaging in commercial transactions for a Canadian company.

There are other categories of exemption for professionals, traders and investors.

\section{BUSINESS IMPLICATIONS}

The ease with which employees and business representatives can cross the borders makes it easier to inadvertently conduct business in the United States. The result is a liability for state or federal taxation, as well as the establishment of sufficient nexus to a location to allow litigation against the corporation to occur within that jurisdiction.

\section{REGULATORY}

\section{A. POLICY}

Power to regulate the interstate commerce is granted to the federal government in the United States. Exercising its authority, Congress established a regulatory regime to handle the network of interstate gas and oil pipelines.

\section{B. $\mathrm{LAW}^{85}$}

The Department of Energy Organization Act ${ }^{86}$ is a federal statute which creates the Department of Energy and grants jurisdiction over natural gas imports and exports to the Secretary of Energy. Under its provisions the various other regulatory jurisdictions are parcelled out among federal administrative agencies. Short- term imports into the United States require authorizations to import. ${ }^{87}$ These take the form of blanket authorizations of terms up to two years. Quarterly reports of actual imports must be made. Long-term imports require the prior approval of the Department of Energy. More information is required to obtain such approvals and monitoring also occurs.

The Federal Energy Regulatory Commission (FERC) is an agency of the United States' Department of Energy that has jurisdiction over wholesale interstate electric rates, hydroelectric licensing, oil pipeline rates and natural gas companies and producers that sell or transport gas in interstate commerce. With respect to the natural gas industry, the chief empowering statute of the FERC is the Natural Gas Act of $1938 .{ }^{88}$

The Natural Gas Act of 1938 provides for the regulation of the transportation of natural gas in interstate commerce, the sale of natural gas in interstate commerce for resale and 
the regulation of the natural gas companies that provide these services, as well as their facilities. Included in this Act is the authority to issue certificates of public convenience and necessity authorizing construction and operation of facilities and the provision of services.

Through a series of orders, culminating in FERC Order $636,{ }^{89}$ the FERC has been deregulating the formerly tightly regulated natural gas regime in existence prior to 1984 . With full implementation of FERC Order 636, interstate pipelines are intended to be able to engage in certain unregulated marketing activities if they meet various tests including: (i) separation of marketing from transportation activities; and (ii) separate costing of transportation from other services.

Regulatory approval of pipeline transportation tariffs occurs in the context of protracted negotiations. General commercial resolution of desirable terms and provisions of pipeline tariffs is taken to the FERC for approval, in order to ensure consistency with policy. Unresolved matters are adjudicated through the administrative law (judicial) branch of the FERC.

The Natural Gas Act of 1938 specifically states that it does not apply to the transportation or sale of natural gas in intrastate commerce or to the local distribution of natural gas. Individual states have taken the jurisdiction to regulate the local distribution companies within their jurisdiction through the various public utility commissions.

\section{BUSINESS IMPLICATIONS}

Tariff provisions of the pipelines are not uniform and some portions can be waived by negotiation between the customer and utility. There is considerable flexibility in an interstate pipeline to customize tariff provisions to suit customer needs. Even after the unbundling contemplated by FERC Order 636 there will be latitude in the quality of service a pipeline company can provide to a customer with the ability to seek and obtain such service.

Reliance on the tariff provisions of a pipeline company will require a transportation customer to familiarize itself with FERC procedures. Considerable commitment in the negotiated and litigated portions of the FERC proceedings is required to maintain an influence over tariff provisions which directly or indirectly affect the commercial viability of individual contracts.

While FERC policy does not generally permit a pipeline to take away rights from individuals without payment of transition costs, the measure of those costs will often depend on the prepositioning of the parties in the FERC proceedings.

89 Order No. 636, Pipeline Service Obligations and Revisions to Regulations Governing SelfImplementing Transportation Under Part 284 of the Commission's Regulations and Regulation of Natural Gas Pipelines After Partial Wellhead Decontrol (8 April 1992) FERC Dockets RM91-11-000 and RM87-34-065. 
The role of state utility commissions is expected to increase as the FERC retreats from its regulatory jurisdiction. An example of the flexing of jurisdictional muscle is currently occurring in California. Similar forays into former federal areas of involvement and jurisdiction are contemplated by several Northeastern and Midwestern states.

There is considerable uncertainty at this time over the ultimate resting place for firm transportation rights under most FERC Order 636 restructurings. There has been a bias toward downstream customers being given the firm rights. ${ }^{90}$ This may conflict with the strategies of a gas marketing company seeking to control its product downstream to the market.

\section{CONCLUSION}

Dispute resolution between Canadian and American trading partners has as many facets as the trading relationship itself.

On the policy level, existing trade talks between the federal levels of governments are formalized. As an offshoot of ongoing implementation talks the FERC, the Department of Energy, the International Trade Commission, Canadian Department of Energy Mines and Resources and Canadian National Energy Board participate in a regularly scheduled series of meetings to deal with gas issues. While there has been expansion of the gas committee talks to include provincial and state representation on occasion, this does not happen in the usual course.

A Canada-United States' Trade Commission was created under the FTA ${ }^{91}$ to supervise the FTA, resolve disputes and oversee its implementation. In the agreements there are dispute settlement mechanisms providing for arbitration or reference to a bi-national panel.

Trade under the FTA and the NAFTA is subject to the joint management of the Trade Commission, ${ }^{92}$ which has cabinet level officers representing each government. The NAFTA also created a permanent secretariat to facilitate the administration of the Commission and the dispute settlement panels. ${ }^{93}$

Under the FTA both parties can enforce their domestic anti-dumping and countervailing duty laws. These provisions are continued in the NAFTA. Enforcement of the duties initially occurs in a domestic forum. Appeal to a bi-national panel is now substituted for judicial review. Under the FTA both governments agreed to meet to resolve issues concerning competition laws. However, there appears to be a shift in the NAFTA where, without a timetable, the parties agreed to meet to consider issues concerning the relationship between competition law and trade.

so Ibid. at 74 . New section 284.242 of regulations.

91 FTA, supra note 6, Part Six, Chapter 18, Article 1802.

92 NAFTA, supra note 7, Part Seven, Chapter 20, Article 2001.

93 Ibid. Part Seven, Chapter 20, Article 2002. 
A trilateral committee has been formed under the NAFTA to consider issues concerning the relationship between competition laws, policies and trade. ${ }^{94}$

Disputes between individuals and NAFTA governments are subject to international arbitration provisions. Disputant individuals in multiple jurisdictions will be encouraged under the NAFTA to use alternate dispute resolution.

In the final resort a company might find that it is a party to litigation in an American court. Courts within the United States are under either federal or state jurisdiction. Federal courts can be either constitutional courts or legislative courts, ${ }^{95}$ the former having the general judicial authority which the federal government possesses. Legislative courts on the other hand have legislated and limited jurisdictions, for example, the Tax Court of the United States.

States have created a separate judicial system pursuant to their own respective constitutions and statutes. The bulk of litigation in the United States occurs in state courts, which have concurrent jurisdiction with federal courts over federal law.

In the event of dispute it is open to the parties to pursue a claim in the appropriate court. Parties may wish to consider if the interpretation of state law is in question, in which case a state court may be more appropriate; or if the validity of a state law or interstate commerce are in question, in which case a party may wish to use the federal court system.

While practical considerations such as perceived impartiality of the court to the triable issue are factors in deciding a preferred trial forum, federal courts must apply state laws and adhere to state court precedent. ${ }^{96}$ Nevertheless there is often a rush among parties to have their preferred forum seized with jurisdiction, particularly when the decision of a federal or state agency would be under review.

Recent decisions make it extremely imprudent to ignore actions arising outside of Canada. ${ }^{97}$ Judgments of American courts, even default judgments, will be enforced by the Canadian courts. Therefore litigation falling out of issues of trading into the United States cannot be wished away merely by staying judgment proof in American jurisdictions. 


\title{
THE LEGAL FRAMEWORK FOR DOING BUSINESS IN RUSSIA: A SUMMARY*
}

\author{
PAUL DRAGER *
}

The Canadian oil and gas industry has been particularly successful in establishing operations in Russia. The author argues that the Canadian penetration of Russia's byzantine legislation, regulation and bureaucracy is due to Canada's long history of governmental and commercial dealings with the former Soviet Union; to Canada's relatively low profile on the international political scene; and to the fact that those involved in the petroleum industries in Canada and Russia share similar experiences in terms of the problems posed by climate, geology and jurisdictional overlap in both countries, experiences which have led to mutual understanding and enhanced co-operation. The author provides an overview of the issues and options which confront a Canadian company in the process of establishing a viable operation in Russia. He suggests that patience, flexibility and long-term planning are the management tools required to succeed in Russia's fluid and complex legal and legislative environment.

\section{TABLE OF CONTENTS}

I. INTRODUCTION $\ldots \ldots \ldots \ldots \ldots \ldots \ldots \ldots \ldots \ldots \ldots \ldots \ldots \ldots$

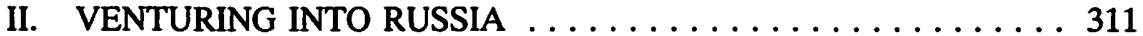

A. CANADIAN BUSINESS IN RUSSIA $\ldots \ldots \ldots \ldots \ldots \ldots 311$

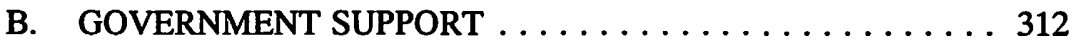

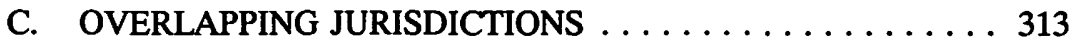

III. LEGAL REGIMES FOR CORPORATE

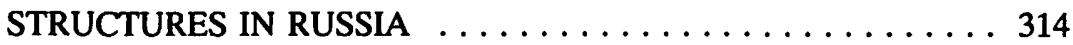

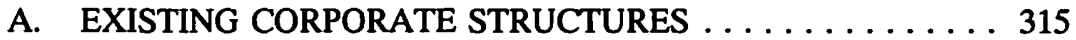

B. NEW CORPORATE STRUCTURES . . . . . . . . . 316

IV. CREATION OF A JOINT STOCK COMPANY $\ldots \ldots \ldots \ldots . \ldots 318$

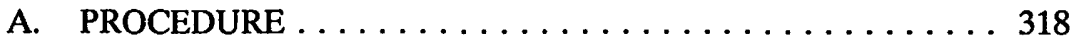

B. HOW TO ESTABLISH THE DEAL . . . . . . . . . 319

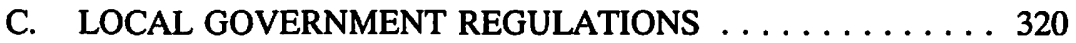

D. RUSSIAN FEDERATION

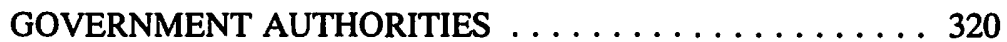

V. THE RUSSIAN TAX FRAMEWORK $\ldots \ldots \ldots \ldots \ldots \ldots \ldots 321$

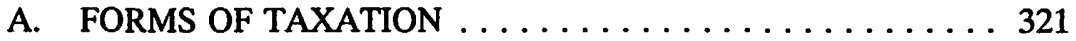

B. TAX CONSIDERATIONS WHEN

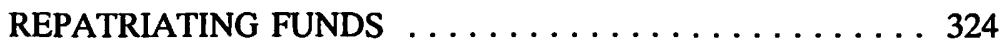

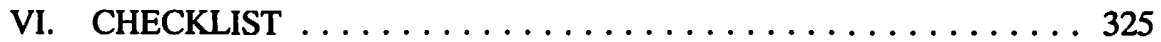

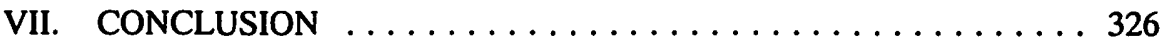

This summary was correct as of the fall of 1993. Significant political and legal changes occurred in the fall and winter of 1993. Russia continues to be a fluid system in 1994.

. $\quad$ Partner, Macleod Dixon, Calgary. The author wishes to acknowledge the assistance he received from Ms. Joanne Cox, Associate Lawyer, Macleod Dixon, in the preparation of this paper. 